\title{
Komunitas Online : Pergeseran Terminologi Komunitas Dari Geddesian Menuju Era Informasi Dalam Konteks Perencanaan Transportasi Perkotaan
}

\author{
Online Communities : Communities Terminology Shift from \\ Geddesian to Information Era in Urban Transportation Planning \\ Context
}

\section{Yudi Basuki ${ }^{1}$, Roos Akbar², Pradono ${ }^{3}$, Miming Miharja}

Diterima : 31 Desember $2012 \quad$ Disetujui: 4 Februari 2013

\begin{abstract}
Abstraksi: Tujuan artikel ini menjelaskan pergeseran gagasan tentang Folk sampai dengan Komunitas Online. Metodologi yang digunakan adalah kajian pustaka untuk membentuk konseptual framework. Terjadi Pergeseran dua gagasan yaitu, yang pertama gagasan Geddes yaitu pada komunitas online aktivitas yang dilakukan manusia tidak hanya pada ruang nyata (real space) namun juga ruang maya (virtual space) yang meretas konsepsi kesatuan geografi. Gagasan kedua adalah konsep sistem aktivitas oleh Manheim tidak lagi hanya berupa aktivitas yang dilakukan di ruang nyata namun juga terdapat aktivitas yang dilakukan pada ruang virtual. Konsep trip generation tidak lagi merujuk pada lokasi berkumpulnya pelaku perjalanan pada suatu kawasan kesatuan geografis tertentu. Konsepsi trip attraction pun tidak lagi selalu merujuk ke pusat kota atau pusat pelayanan kota namun bergantung pada kesepakatan anggota komunitas online dalam melakukan pertemuan fisik.
\end{abstract}

Kata kunci : pergeseran gagasan, ruang nyata, ruang maya, komunitas online.

Abstract: The purpose of this article is to explain the shift of idea in the notion of Folk to Online Communities. The methodology used is a literature review to establish the conceptual framework. There are two shift ideas, the first is the idea of Geddes, while the online community committed human activity not only in real space but also the virtual space that paved the conception of the unity of geography. The second is that the activity system concept was initiated Manheim no longer just the activities carried out in real space but also the activity is conducted in a virtual space. Concept of trip generation no longer refers to the location of the gathering of traveling performers in a particular geographic area unit. Conception of trip attraction was also no longer always refers to the city center or the center of town services but depends on the deal online community members in conducting physical meetings.

Keywords: shifting ideas, real space, cyberspace, online communities

\footnotetext{
${ }^{1}$ Teknik Perencanaan Wilayah dan Kota, Universitas Diponegoro

J1. Prof. Soedharto, SH Tembalang - Semarang

${ }^{2}$ Program Doktor Perencanaan Wilayah \& Kota SAPPK ITB

Labtek IX-A Lantai 2, Jl. Ganesha 10, Bandung 40132
} 


\section{Pendahuluan}

Gagasan Patrick Geddes tentang keterkaitan antara Folk-Work-Place telah menjadi dasar teori substantif dalam perencanaan wilayah dan kota (Geddes, 1915). Pada perkembangannya dalam studi-studi perencanaan wilayah dan kota, Folk kemudian dimaknai dengan komunitas (yang pada awalnya meminjam konsep dari sosiologi, yaitu suatu kesatuan sosial yang tinggal di suatu kawasan/ geografi tertentu yang berbagi sistem nilai yang sama dan memiliki keterikatan sosial tertentu). Komunitas ini dapat sangat beragam tergantung pada karakteristik anggota yang ada dan memiliki skala tertentu pula tergantung dari besarnya kawasan sebagai tempat tinggal. (Soekanto, 1990)

Pada studi transportasi, Manheim menginspirasikan banyak peneliti dengan gagasannya tentang sistem akitivitas, sistem pergerakan dan sistem transportasi (Manheim, 1979). Pada perencanaan transportasi profil permintaan (demand) sering kali merujuk kepada karakter pelaku yang merupakan bagian dari suatu populasi dalam sistem aktivitas. Dalam perencanaan transportasi profil permintaan sering dimanifestasikan dalam zona bangkitan (generation) atau tarikan (attraction) yang merujuk pada guna lahan tertentu dan merupakan representasi dari aktifitas bagian dari populasi yang merupakan manifestasi dari folk, work dan place dalam gagasan Patrick Geddes.

Seiring dengan perkembangan teknologi informasi dan komunikasi folk, work dan place yang dalam terminologi transportai senada dengan sistem aktifitas juga mengalami perkembangan yang berakibat pada beragamnya kumpulan tersendiri atau ada suatu kumpulan anggota masyarakat yang berbagi suatu sistem nilai dan/ dalam melakukan kegiatan pergerakan/ transportasi. Kumpulan ini ada yang memanfaatkan jaringan internet sebagai salah satu fasilitas kemajuan teknologi informasi dan komunikasi yang dikenal dengan komunitas online.

Sangat menarik dan menjadi penting untuk mengkaji perkembangan atau pergeseran gagasan tentang folk sampai dengan komunitas online, terutama yang nantinya akan berimplikasi pada perjalanan yang ditimbulkan sebagai bagian dari kajian perencanaan transportasi. Tujuan dari artikel ini adalah menjelaskan pergeseran gagasan tentang Folk sampai dengan Komunitas Online. Metodologi yang digunakan adalah kajian pustaka untuk membentuk kerangka konseptual tentang pergeseran gagasan.

\section{Kajian Pustaka}

Kajian pustaka ini juga merupakan inti dari metodologi penyusunan artikel ini yang terdiri dari pendefinisian komunitas, perkembangan pendekatan perencanaan substantif, pemahaman akan permintaan transportasi, serta perkembangan komunitas yang terbentuk sebagai akibat dari teknologi informasi dan komunikasi.

\section{Definisi Komunitas}

Komunitas berasal dari bahasa Latin communitas yang berarti "kesamaan", kemudian dapat diturunkan dari communis yang berarti "sama, publik, dibagi oleh semua atau banyak". Selanjutnya definisi komunitas dalam artikel ini lebih merujuk kepada pendapat Soerjono Soekanto, seorang sosiolog. Komunitas yaitu yang menunjuk pada bagian masyarakat yang bertempat tinggal di suatu wilayah (geografis) dengan batas-batas tertentu dan faktor utama yang menjadi dasar adalah interaksi yang lebih besar di antara anggotanya, dibanding dengan penduduk di luar batas wilayahnya. Soekanto (1990). Masih mernurut Soekanto, komunitas adalah sebuah kelompok sosial dari beberapa organisme yang berbagi lingkungan, umumnya memiliki ketertarikan yang sama. Dalam komunitas manusia, individu-individu di dalamnya dapat memiliki maksud, kepercayaan, sumber daya, preferensi, kebutuhan, risiko dan sejumlah kondisi lain yang serupa. Istilah community dapat di terjemahkan sebagai "masyarakat setempat", istilah lain menunjukkan 
pada warga-warga sebuah kota, suku, atau suatu bangsa . Apabila anggota-anggota suatu kelompok baik itu kelompok besar atupun kecil, hidup bersama sedemikian rupa sehingga mereka merasakan bahwa kelompok tersebut dapat memenuhi kepentingan-kepentingan hidup yang utama, maka kelompok tadi dapat disebut masyarakat setempat. Intinya mereka menjalin hubungan sosial (social relationship).

Dapat disimpulkan bahwa masyarakat setempat (community) adalah suatu wilayah kehidupan sosial yang ditandai oleh suatu derajat hubungan sosial yang tertentu. Dasardasar dari masyarakat setempat adalah lokalitas dan perasaan semasyarakat setempat. Jadi pada intinya definisi komunitas adalah sekumpulan orang orang yang berada pada kawasan tertentu dan memiliki nilai dan ikatan bersama.

\section{Pemikiran Patrick Geddes Tentang Folk-Work-Place}

Patrick Geddes (lahir pada tanggal 2 Oktober 1854 dan wafat pada tanggal 17 April 1932) adalah seorang ahli biologi Skotlandia, sosiolog, ahli geografi, filantropis dan perencana kota. Dia dikenal karena pemikiran inovatif di bidang perencanaan kota dan sosiologi. Geddes dipengaruhi oleh filsuf Herbert Spencer (1820-1903) dan Frederic Le Play (1806-1882) dan memperluas teori sebelumnya tentang konsep perencanaan wilayah.

Ia mengadopsi teori Spencer bahwa konsep evolusi biologis dapat diterapkan untuk menjelaskan evolusi masyarakat, dan mendasarkan pada analisis Le Play terhadap unit kunci dari masyarakat sebagai, 'Lieu, Travail, Famille' ('Place, Work, Family), tetapi mengubah "family" menjadi "folk". Dalam teori ini, keluarga dipandang sebagai pusat 'unit biologis dari masyarakat manusia'. Menurut Geddes, dari 'keluarga yang stabil dan rumah sehat' menjadikan kondisi yang baik untuk perkembangan mental dan moral bagi generasi mendatang untuk mampu dan berpartisipasi dalam kehidupan. "

Geddes mendasarkan pada teori lingkaran Le Play tentang lokasi geografis yang menyajikan keterbatasan lingkungan dan kesempatan. Argumen utamanya adalah bahwa kombinasi antara geografi fisik, ekonomi pasar dan antropologi akan, menghasilkan dasar kehidupan sosial ". Dengan demikian, pembahasan sosiologi dikembangkan menjadi ilmu "interaksi manusia dengan lingkungan alam". Geddes juga mengembangkan metodologi dalam interaksi manusia dengan lingkungan alam tersebut melalui teknik survey. Menurut Geddes perencanaan kota dapat dipandang sebagai suatu sosiologi terapan.

Gagasan Patrick Geddes tentang folk-work- place sebenarnya ditujukan untuk mengkritik perencanaan yang hanya berorientasi pada ekonomi pada waktu itu akibat revolusi industri. Karena menurut Geddes hasil dari abad industri (paleotechnic) adalah permukiman kumuh (Geddes, 1915, halaman 115-119) Menurut Geddes wealth (kemakmuran) versi ekonomi hendaknya juga merujuk pada life (kehidupan) yang baik. Kehidupan yang lebih baik adalah hubungan yang lengkap antara organisme, fungsi dan lingkungannya (Geddes, 1915 halaman 392) Untuk mewujudkan kehidupan yang lebih baik tersebut maka perlu untuk mensinkronkan antara folk-work-place secara berkesinambungan, hari ke hari, tahun ke tahun bahkan dari generasi ke generasi.(Geddes, 1915 halaman 409).

Gagasan Patrick Geddes inilah yang memulai pendekatan perencanaan yang procedural menjadi substantive karena menyarankan cara surey untuk menyusun suatu rencana kota secara sinoptik dan menyeluruh antara lain situasi, topografi, dan alam lingkungan; komunikasi, tanah dan air; industri, pabrik dan komersial; populasi; kondisi kota ; dan rencana kota. (Geddes, 1915, halaman 356). Meskipun gagasan Patrick Geddes merupakan gagasan yang sudah cukup lama namun banyak diikuti khususnya pada kaum new urbanisme. 


\section{Pendekatan Permintaan Transportasi}

Transportasi adalah permintaan turunan (derived demand) dimana terjadi perpindahan manusia dan atau barang dari satu tempat ke tempat lain untuk memenuhi kebutuhan baik yang sifatnya dasar (kebutuhan pokok) maupun sekedar untuk kenyamanan (Manheim, 1979; Morlok, 1997)). Perencanaan transportasi perkotaan juga menghadapi tantangan sebagai akibat dari perubahan karakteristik populasi/penduduk, ekonomi perkotaan, sosial, regulasi, dan teknologi. (Meyer and Miller, 2001 halaman 13).

Pemahaman akan permintaan transportasi didasari oleh pemahaman akan hubungan mendasar antara system transportasi dan system aktivitas. Manheim mengatakan bahwa sistem transportasi pada suatu wilayah sangat erat hubungannya dengan system social dan ekonomi. Sistem transportasi akan selalu mengakibatkan pertumbuhan dan perubahan sistem ekonomi. Pertumbuhan dan perubahan system ekonomi ini akan juga mengubah kembali system transportasi . (Manheim 1979, halaman 12).

Hubungan mendasar tersebut dapat dijelaskan dengan gambar 1

Keterangan:

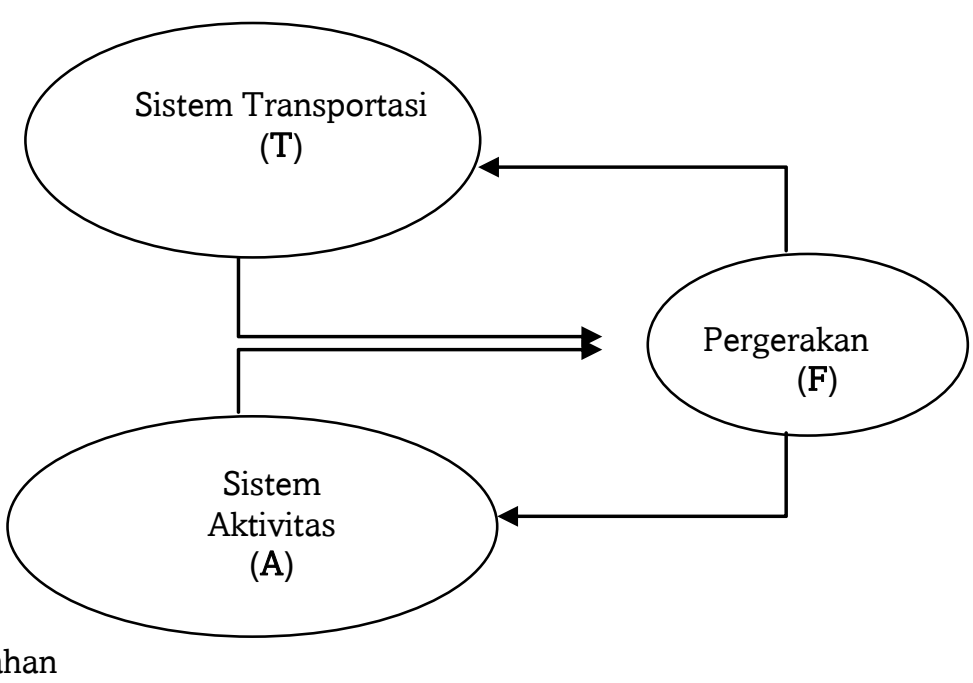

Sumber : Manheim, 1979 halaman 13 (digambar ulang)

Gambar 1. Hubungan Mendasar Sistem Transportasi dan Sistem Aktivitas

Menurut Manheim tiga variabel dasar yang dapat menjelaskan hubungan transportasi dan sistem aktivitas adalah :

"T adalah sistem transportasi yang merupakan pelayanan atau supply dari transportasi baik sarana maupun prasarana transportasi; A yaitu sistem aktivitas yang merupakan pola aktivitas sosial ekonomi; $\mathrm{F}$ yaitu pola pergerakan atau perjalanan dari sistem transportasi yang meliputi asal, tujuan, rute, dan volume barang dan manusia yang melakukan perjalanan."

Pola perjalanan dalam sistem transportasi diturunkan dari sistem transportasi dan sistem aktivitas. Pola perjalanan yang ada akan menyebabkan perubahan sistem aktivitas melalui pola pelayanan transportasi yang tersedia dan melalui konsumsi sumber daya yang menjadi penyedia pelayanan. Pola perjalanan yang ada juga akan menyebabkan perubahan pada sistem transportasi dengan pembangunan pelayanan transportasi atau memodifikasi pelayanan yang ada untuk merespon atau mengantisipasi perjalanan. Yang perlu diingat adalah A merupakan simbol yang tidak sederhana. Dalam metropolitan area atau 
megapolitan area sistem aktivitas ini mengandung banyak subsistem yang saling tumpang tindih dan berhubungan, seperti struktur sosial, institusi politik, dan sebagainya.

Dalam perencanaan transportasi dikatakan bahwa sistem aktivitas adalah yang menyebabkan permintaan transportasi. (Manheim 1979, halaman 17). Pola aktivitas individu dapat didefinisikan sebagai pilihan yang dibuat seperti pekerjaan termasuk jenis pekerjaan dan pendapatan; tempat tinggal termasuk lokasi, tipe rumah, tipe tetangga, akses ke sekolah dan pasar, interaksi dengan tetangga; pola konsumsi; belanja dan aktivitas belanja lainnya seperti memesan barang dan pelayanan lainnya, banking; aktivitas sosial dan rekreasi seperti berkunjung dan tamasya pada akhir pekan dan liburan (Manheim 1979, halaman 18). Hal ini juga senada dengan Morlok yang mengklasifikasikan maksud pergerakan menjadi maksud bekerja, sekolah, dan lainnya. (Morlok, 1997).

Masing masing individu mempunyai konsepsi tersendiri dari pola aktivitas yang merupakan pemenuhan dan kenyamanan kebutuhan hidup. Hal ini merupakan permintaan dasar yang menyebabkan keputusan individu atau keluarga. Hubungan antara pemenuhan kebutuhan dan pilihan perjalanan dapat dijelaskan dengan tingkatan pilihan individu seperti pada gambar 2

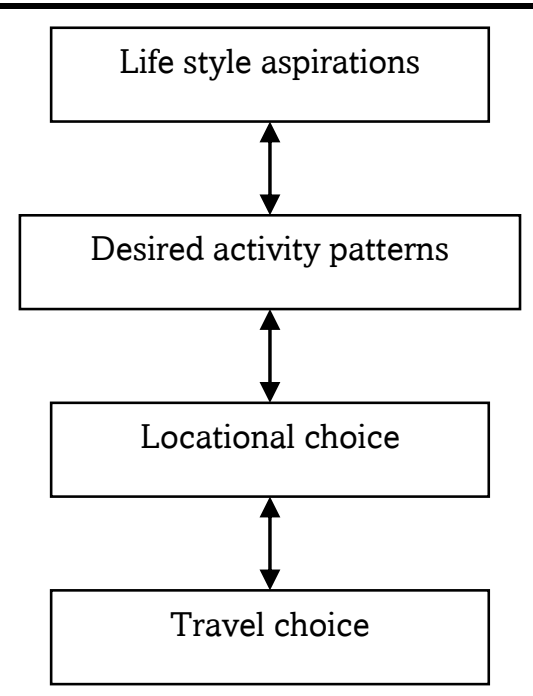

Sumber : Manheim, 1979 halaman 61.

\section{Gambar 2. Tingkatan Pilihan Individu}

Bagan di atas menjelaskan ada beberapa tingkat pilihan dari individu yang harus dilakukan. Pada tingkatan tertinggi pada umumnya pada tingkat paling dasar adalah pola keinginandari aktifitas yang mencerminkan aspirasi gaya hidup seseorang. Kemudian untuk melakukan aktivitasnya seseorang harus berada pada lokasi atau tempat dan waktu tertentu. Hal ini yang menyebabkan seseorang memilih lokasi seperti lokasi bermukim dan lokasi bekerja. Pada akhirnya seseorang baru memilih dimana, kemana, kapan dan dengan apa melakukan perjalanan. Berdasarkan pendekatan ini maka dapat dikatakan bahwa fungsi permintaan transportasi merupakan representasi dari perilaku manusia (Manheim, 1979 halaman 63).

Senada dengan Manheim, Kanafani juga mengatakan bahwa permintaan transportasi berdasarkan pilihan perjalanan dapat dibagi menjadi dua yaitu yang bersifat jangka panjang (long range) dan jangka pendek (short range). Yang bersifat jangka panjang ditentukan oleh pilihan lokasi bekerja dan bermukim serta pilihan kepemilikan kendaraan sementara yang 
bersifat jangka pendek ditentukan oleh penggunaan harian dari kendaraan, , tujuan, waktu, dan rute yang dipilih untuk keperluan bukan bekerja. (Kanafani, 1983 halaman 116)

Selanjutnya gagasan ini memunculkan konsep dalam keruangan tentang adanya lokasi yang menjadi pembangkit perjalanan (trip generation) dan lokasi yang menjadi penarik perjalanan (trip attraction). (Manheim, 1979; Kanafani 1983; Morlok, 1997). Lokasi yang menjadi pembangkit perjalanan biasanya identik dengan lokasi perumahan (biasanya di pinggir kota) sedangkan lokasi yang menjadi penarik perjalanan adalah identik dengan lokasi tempat kerja atau pusat perkotaan. Kesesuaian antar lokasi yang menjadi pembangkit dan lokasi yang menjadi penarik perjalanan akan meningkatkan perjalanan. Selain pusat kota, lokasi yang menjadi penarik perjalanan juga dapat tersebar dalam pusat pusat pelayanan perkotaan seperti sekolah dan pasar. Semakin tingginya intensitas hubungan lokasi pembangkit dan penarik perjalanan maka akan semakin tinggi arus perjalanan yang terjadi. Pola perjalanan yang terjadi dapat mengindikasikan ketergantungan dari kawasan pinggiran terhadap pusat kota yang memunculkan beberapa permasalahan transportasi seperti kemacetan.

Pada kasus sebaliknya yaitu apabila intensitas hubungan lokasi pembangkit dan penarik perjalanan semakin rendah maka arus perjalanan yang terjadi akan semakin kecil. Pada kasus ini ketergantungan pada pusat kota dan pusat pelayanan perkotaan menjadi semakin rendah. Sebagai contoh apabila tempat bekerja orang tidak harus di pusat kota maka arus ke pusat kota dari pinggiran akan berkurang.

Gagasan ini juga menimbulkan konsep yang disebut pola pergerakan. Pola pergerakan dapat dikelompokkan menjadi maksud, tujuan, moda dan frekwensi. Maksud pergerakan sering dikelompokkan menjadi maksud untuk bekerja, sekolah dan aktivitas lainnya. Tujuan pergerakan biasanya merujuk pada lokasi dari mana dan kemana orang melakukan pergerakan (dari pinggiran kota ke pusat kota). Moda yang digunakan adalah jenis kendaraan yang digunakan. Frekwensi pergerakan adalah jumlah pergerakan yang dilakukan (harian, mingguan, bulanan) (Manheim, 1979; Kanafani 1983; Morlok, 1997)

\section{Pergeseran Hubungan Masyarakat Akibat Teknologi Informasi dan Komunikasi.}

Perkembangan aktivitas perkotaan di seluruh dunia dewasa ini berlangsung sangat pesat seiring dengan perkembangan teknologi, terutama yang menyangkut informasi dan komunikasi. Perkembangan ini yang menggeser aktivitas industri perkotaan yang didominasi oleh penggunaan sumber daya alam menjadi aktivitas perkotaan berdasarkan arus informasi yang dikenal dengan the informational city (Castells, 1989). Pada awalnya kemajuan teknologi informasi dan komunikasi telah menyebabkan perusahaan transnasional, kelompok, wilayah dan masyarakat saling terhubung dan saling tergantung membentuk masyarakat jejaring (network society) (Castells, 2000 dalam Albrechts, 2005). Keterhubungan ini diyakini akan menyebabkan transfer informasi dan pengetahuan sehingga menyebabkan perkembangan aktivitas lain sepert aktivitas ekonomi, pendidikan bahkan politik. Munculnya masyarakat jejaring telah menggeser paradigma pembangunan industri menjadi pembangunan berbasis informasi (Castells, 2000 dalam Gustavo, 2006).

Pada perkembangannya hal ini mengakibatkan perubahan definisi masyarakat (society) menjadi masyarakat jejaring (network society) (Gustavo, 2006). Pada masyarakat jejaring, pola hubungan sosial masyarakat berubah dari struktural hirarkis menjadi lebih fleksibel. Pola hubungan sosial masyarakat tidak lagi didasarkan pada kedekatan jarak geografis namun pada kemudahan akses informasi dan kesamaan kepentingan. Selain itu, muncul perubahan dari masyarakat yang terhubung secara langsung (fisik) menjadi terhubung secara virtual (maya) dan membentuk kelompok sosial baru dengan sistem nilai dan keterikatan yang beragam. Perubahan ini juga menimbulkan transisi dari struktur sosial yang rigid dan hirarkis karena dipengaruhi oleh jarak menjadi struktur yang lebih fleksibel 
dan tidak dipengaruhi oleh jarak lagi. (François, 2009 halaman 12). Transisi ini juga dapat membentuk pola hidup (lifestyle) yang baru (Gamal, 2010 halaman 26). Transisi ini dapat dilihat pada Gambar 3.

Perubahan pola hubungan sosial masyarakat ini tidak hanya terjadi di negara maju namun juga di negara berkembang sehingga gejala perubahan hubungan sosial akibat masyarakat jejaring dapat dikatakan telah mendunia. Hal ini tergantung dari ketersediaan teknologi informasi dan komunikasi yang cenderung menjadi semakin mudah dan murah.

Perubahan komunitas juga digagas oleh Hampton dimana dikatakan bahwa komunitas di tingkat wilayah seperti permukiman dapat dikatakan dekat secara fisik belum tentu dapat berhubungan (Hampton, 2007 halaman 3). Internet memungkinkan komunikasi dimana orang tidak harus terhubung secara bersamaan di ruang yang sama untuk berkomunikasi secara efektif. Hal ini digagas sebagai e-neighborhood. (Hampton, 2007 halaman 31). Pada skala perkotaan hal ini juga diyakini akan mengubah struktur ruang kota (Graham, 2001; Audirac, 2005)

Perkembangan ini juga mengubah konsep keruangan (spatial) dari spatial reality menjadi spatial virtual. Ruang itu mengalir dan waktu menjadi relatif (Castells, 2010). Pergerakan maya (virtual mobility) dan akses pada jejaring (cyberspace) memungkinkan orang untuk terhubung dalam berbagai aktivitas pada setiap waktu dan tempat. (Ohmori, 2006; Golob, 2001).
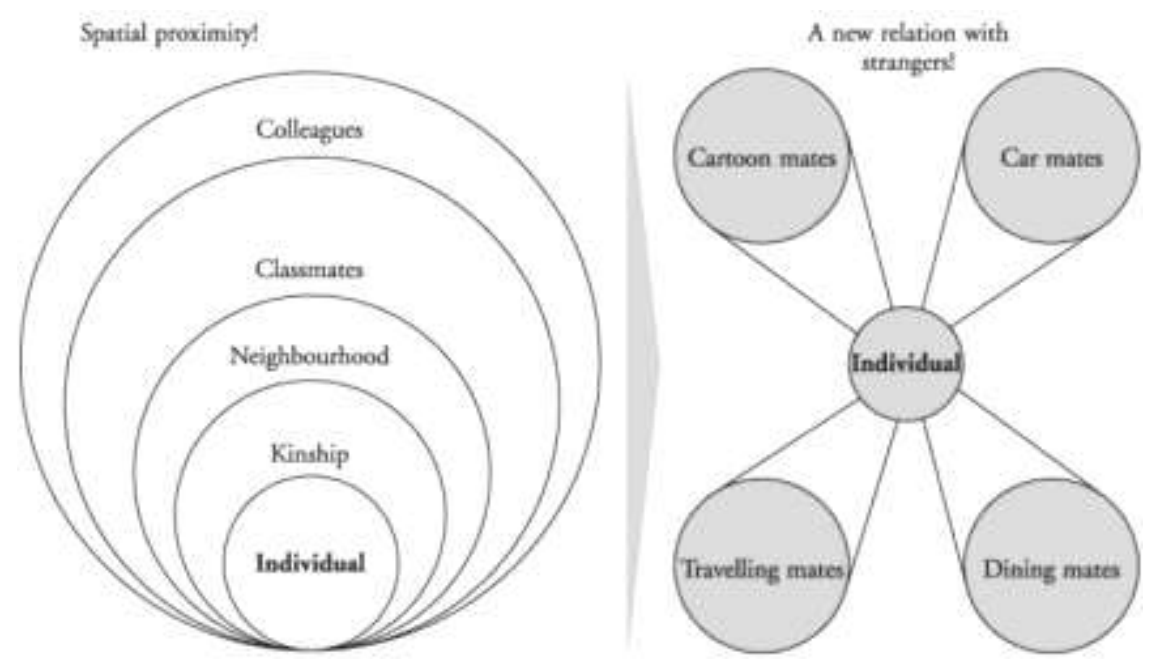

Sumber : Francois, 2009 halaman 11.

Gambar 3.Transisi Struktur Sosial Masyarakat

Komunitas Online Sebagai Bentuk Komunitas Baru Akibat Teknologi Informasi dan Komunikasi.

Saat ini, jutaan orang menggunakan internet sebagai sarana, membuat dan memelihara hubungan sosial dengan orang-orang yang berbagi pengalaman umum, kepentingan, atau keprihatinan. Aktivitas ini menimbulkan suatu terminologi baru dalam masyarakat yang dikenal dengan nama komunitas online. Ada banyak definisi tentang komunitas online ini, namun dalam artikel ini lebih menggunakan definisi dari Hummel \& Lechner. Komunitas online didefinisikan sebagai suatu kolektivitas, besar anggota sukarela yang tujuan utamanya adalah anggota dan kesejahteraan kolektif, anggota-anggota yang berbagi pengalaman, pengetahuan bagi anggota lain, dan yang berinteraksi satu sama lain 
dan memberikan kontribusi pada kolektivitas menggunakan internet. (Hummel \& Lechner, 2002)

Komunitas online dapat memiliki struktur yang lemah atau kuat tergantung pada komitmen anggota. Kemudahan aplikasi di internet memudahkan orang untuk membentuk komunitas online (online communities) berdasarkan kesamaan kepentingan dan ketertarikan. Komunitas online yang terbentuk dapat beranggotakan banyak orang ataupun terbatas. Jenis komunitas online pun beragam. Keberadaan komunitas online juga dapat bertahan lama ataupun hanya sebentar. Aktivitas anggota komunitas online juga beragam namun pada umumnya adalah berupa pertukaran informasi dan pengetahuan. Dalam keterhubungannya orang dapat membentuk suatu komunitas online baru berdasar kepentingannya. Kecenderungan adanya face book, twitter, mailling list menunjukkan orang tergabung dalam kelompok online yang tidak tunggal dan bermacam macam jenisnya.

Kepentingan yang mendorong terbentuknya komunitas online merupakan representasi dari aktualisasi diri manusia yang tidak cukup hanya memenuhi kebutuhan primer dan sekundernya (Maslow dalam Williams, 1995). Komunitas online ini sangat beragam mulai dari pertemanan lama maupun baru, komunitas sesama penggemar kegiatan atau hobi, sampai kepada komunitas yang dipicu oleh aktivitas tertentu seperti sumbangan bencana dan sebagainya. Hummel \& Lechner (2002) mengklasifikasikan komunitas online menjadi lima yaitu: (1) gaming communities: (2) communities of interest. (3) consumer-to-consumer communities (C2C): (5) business-to-business communities (B2B)

Dalam komunitas online, orang dapat beraktivitas tanpa harus bertemu secara langsung. Hal ini yang awalnya menjadi keyakinan bahwa sebagian besar urusan dapat diselesaikan dengan tanpa harus bertemu. Namun pada perkembangannya manusia sebagai makhluk sosial masih membutuhkan pertemuan fisik.

\section{Analisis dan Sintesa Kajian Pustaka}

Analisis pada artikel ini murni didasarkan pada kajian pustaka dan terbagi menjadi dua bagian yaitu pergeseran folk sebagai gagasan Patrick Geddes menjadi apa yang sekarang dikenal sebagai komunitas online dan pergeseran tersebut dalam konteks perencanaan transportasi.

\section{Pergeseran Folkmenjadi Komunitas Online}

Dalam konteks Patrick Geddes, folk dimanifestasikan dalam kumpulan orang dalam suatu wilayah geografis. Hal ini senada dengan terminologi komunitas sehingga folk dapat dimanifestasikan sebagai komunitas. Folk sebagai manifestasi komunitas dapat berjenjang mulai dari ketetanggaan (neighborhood) sampai kepada penduduk kota. Folk sebagai manifestasi komunitas ini juga tidak dapat lepas dari gagasan work dan place sebagai satu kesatuan yang saling berpengaruh. Gagasan Geddes melihat bahwa folk dan work diwadahi dalam suatu kawasan yang dikenal dengan place.(Geddes, 1915). Place dalam konsepsi Geddes masih merujuk pada suatu terminologi bahwa place merupakan kawasan tertentu di muka bumi sebagai kesatuan geografis. Sistem sosial yang terjadi juga merupakan sistem sosial yang berdasar pada kepentingan dan nilai yang didasarkan pada struktur sosial berbasis geografis.

Pada perkembangannya komunitas dapat menggunakan teknologi informasi dan komunikasi seperti internet untuk berinteraksi dan beraktivitas. Komunitas online merupakan salah satu contoh bentuk interaksi dan aktivitas manusia yang tidak lagi harus menggunakan place berdasarkan konsepsi kesatuan geografis. Komunitas ini merupakan kelompok yang terbentuk berdasarkan minat dan kesepakatan bersama dengan 
memanfaatkan ruang maya (virtual space) dalam koneksi internet. (Hummel \& Lechner, 2002). Kelompok dengan sistem nilai dan kesepakatan bersama ini meretas hubungan struktur sosial yang lama menjadi struktur sosial yang baru yang lebih didasarkan pada kesamaan kepentingan. Pergeseran gagasan Folk dari Geddes menjadi komunitas online dapat dilihat pada gambar 4.

Pada gagasan Geddes, place yang menjadi ruang berlangsungnya work dan tempat beradanya folk merupakan kesatuan geografi, sedangkan pada komunitas online aktivitas yang dilakukan manusia tidak hanya pada ruang nyata (real space) namun juga ruang maya (virtual space). Aktivitas yang terjadi juga sangat tergantung pada kelompok (group) yang terbentuk berdasarkan peminatan dan kesepakatan bersama.

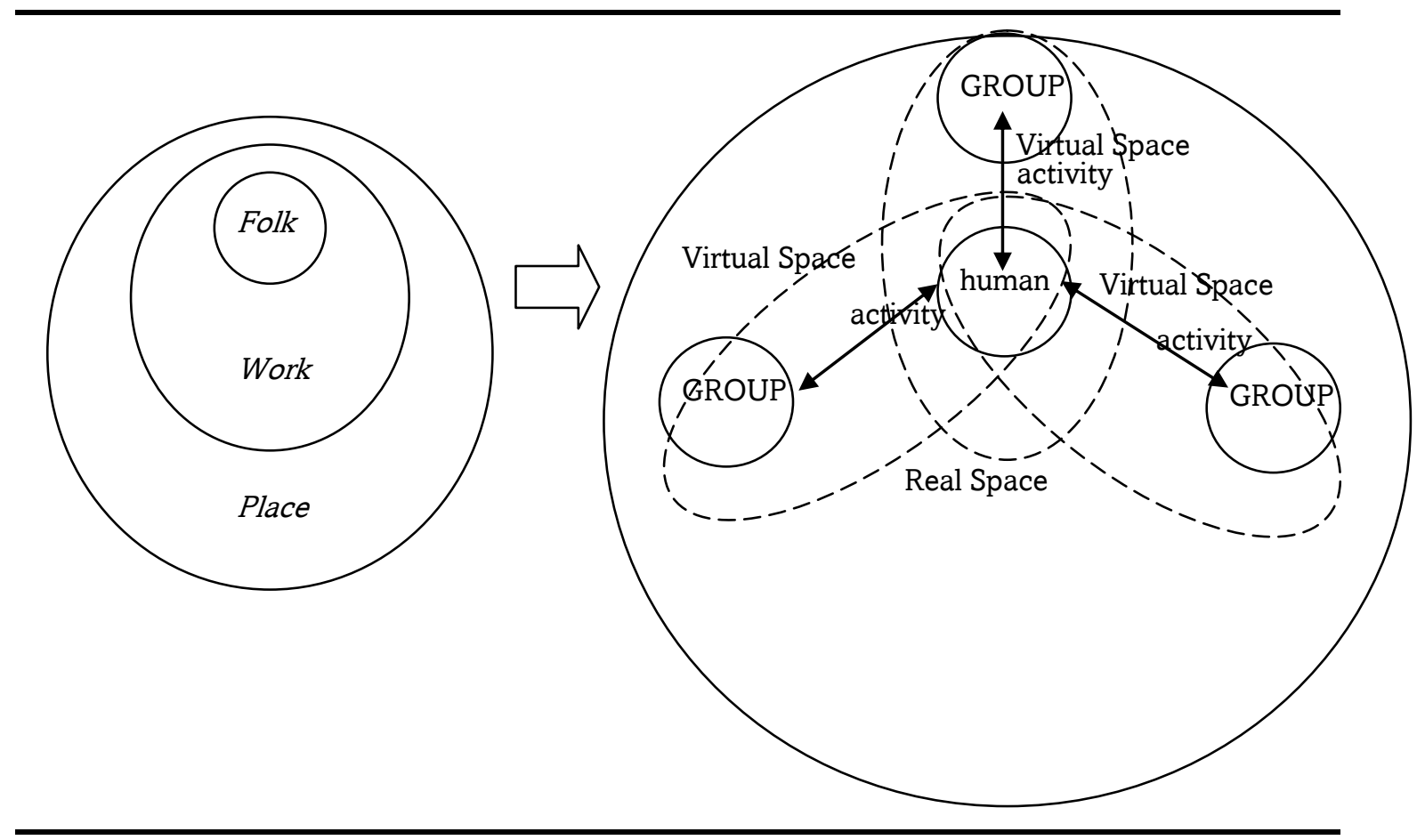

Gambar 4. Pergeseran Folkmenjadi Komunitas Online

\section{Pergeseran Komunitas Dalam Konteks Perencanaan Transportasi}

Dalam konsepsi Geddes selain folk adalah work yang merupakan manifestasi dari aktivitas folk untuk memenuhi kebutuhannya. Dalam teori transportasi apabila kebutuhan seseorang tidak dapat dipenuhi pada lokasi tersebut maka terjadilah pergerakan (trip) karena transportasi adalah kebutuhan turunan. Pergerakan ini merupakan perpindahan orang atau barang dari suatu tempat (place) ke tempat lain menggunakan moda tertentu. Perpindahan orang atau barang ini melahirkan konsep tempat asal (origin) dan tempat tujuan (destination). Tempat asal perjalanan dalam permintaan transportasi sering disebut trip generation dan tempat tujuan perjalanan sering disebut sebagai trip attraction.

Jenis perjalanan yang terjadi dapat dibedakan berdasarkan kapan terjadinya. Perjalanan dapat terjadi bersifat harian seperti untuk bekerja, sekolah dan belanja harian, namun juga dapat terjadi mingguan, bulanan atau tahunan seperti untuk kepentingan berlibur akhir pekan, berkunjung ke sanak saudara ataupun pemenuhan kebutuhan sosial lainnya (Manheim, 1979; Kanafani, 1983). Sehingga dari telaah ini dapat disimpulkan 
bahwa konsep folk-work- place dari Geddes senada dengan konsep sistem transportasisistem aktifitas-perjalanan yang digagas oleh Marvin L Manheim.

Pada perkembangannya komunitas dapat beragam baik secara tempat tinggal (place) maupun aktivitasnya (work). Hal ini akan berakibat pada perkembangan perjalanan itu sendiri baik dari jenis ragamnya ataupun intensitasnya. Skala perjalanannya juga berkembang dari perjalanan lokal (untuk kepentingan sekolah) menjadi perjalanan regional bahkan internasional. Hal ini disebabkan karena aktivitas (work) dari pelaku perjalanan (folk) yang pada perkembangannya tidak sederhana lagi. Hal ini dapat dijelaskan dengan pilihan akan kebutuhan manusia yang berimplikasi pada jangka panjang seperti pilihan lokasi perumahan dan yang berimplikasi pada jangka pendek seperti pilihan tujuan dan penggunaan moda.(Manheim, 1979)

Selanjutnya gagasan ini memunculkan konsep dalam keruangan tentang adanya lokasi yang menjadi pembangkit perjalanan (trip generation) dan lokasi yang menjadi penarik perjalanan (trip attraction). Lokasi yang menjadi pembangkit perjalanan biasanya identik dengan lokasi perumahan (biasanya di pinggir kota) sedangkan lokasi yang menjadi penarik perjalanan adalah identik dengan lokasi tempat kerja atau pusat perkotaan. Lokasilokasi ini kemudian sering dikelompokkan berdasar homogenitasnya menjadi suatu zona. (Kanafani, 1983). Hal ini juga sejalan dengan konsepsi folk dan place dari Geddes dimana tempat berkumpulnya folk dalam suatu place dapat diidentikkan dengan konsepsi zona. Kesesuaian antar lokasi yang menjadi pembangkit dan lokasi yang menjadi penarik perjalanan akan meningkatkan perjalanan. Selain pusat kota, lokasi yang menjadi penarik perjalanan juga dapat tersebar dalam pusat pusat pelayanan perkotaan seperti sekolah dan pasar.

Semakin tingginya intensitas hubungan lokasi pembangkit dan penarik perjalanan maka akan semakin tinggi arus perjalanan yang terjadi. Pola perjalanan yang terjadi dapat mengindikasikan ketergantungan dari kawasan pinggiran terhadap pusat kota yang memunculkan beberapa permasalahan transportasi seperti kemacetan.

Pada kasus sebaliknya yaitu apabila intensitas hubungan lokasi pembangkit dan penarik perjalanan semakin rendah maka arus perjalanan yang terjadi akan semakin kecil. Pada kasus ini ketergantungan pada pusat kota dan pusat pelayanan perkotaan menjadi semakin rendah. Sebagai contoh apabila tempat bekerja orang tidak harus di pusat kota maka arus ke pusat kota dari pinggiran akan berkurang. Kedua pendekatan ini masih memandang tempat (place) sebagai unit geografi baik dalam tempat asal komunitas maupun tempat tujuan perjalanan.

Seiring perkembangannya, teknologi informasi dan komunikasi diyakini akan mengurangi pergerakan manusia atau meniadakan jarak (death of distance) (Cairncross, 1997). Beberapa kegiatan yang menggunakan teknologi informasi seperti teleconference dan tele education telah mengurangi pergerakan manusia. Dalam aktivitas bekerja, teknologi informasi dan komunikasi hanya akan mengubah konsep rumah dan tempat kerja dimana pekerjaan seseorang dapat diselesaikan di rumah dan hasilnya dikirim melalui jaringan (Mitchell 2006 dalam Castells, 2006). Dalam hal ini konsep place dan work dari Patrick Geddes tidak lagi merujuk pada kawasan dalam terminologi geografi dan konsep trip generation dan trip attraction dari Manheim dan Kanafani mulai mengalami pergeseran karena interaksi antar manusia tidak harus dengan pertemuan fisik namun dapat dilakukan lewat jaringan telekomunikasi dan informasi.

Pada komunitas online pergeseran konsepsi tidak hanya pada place namun juga pada folk dimana seseorang dalam komunitas online tidak harus terikat secara geografi namun cukup terikat secara minat dan nilai (Hummel \& Lechner 2002).

Pada pendekatan transportasi fenomena komunitas online ini juga telah mengoreksi konsep trip generation dan trip attraction. Konsep trip generation dalam komunitas online tidak lagi merujuk pada lokasi berkumpulnya pelaku perjalanan (sebagai contoh pada 
permukiman tertentu). Lokasi trip generation bisa tersebar dan tidak terkumpul pada suatu kawasan kesatuan geografis tertentu. Anggota komunitas online dapat berlokasi di tempat yang sama namun lebih sering tersebar tidak hanya dalam skala lokal, perkotaan namun juga regional bahkan internasional. (Hummel \& Lechner 2002) Hal ini mengakibatkan konsep zona untuk trip generation menjadi tidak relevan lagi. Untuk konsepsi trip attraction pada komunitas online juga mengalami pergeseran. Sama seperti pergeseran konsepsi trip generation pada komunitas online maka lokasi dari trip attraction pun juga tidak lagi selalu merujuk ke pusat kota atau pusat pelayanan kota. Lokasi trip attraction sangat bergantung pada kesepakatan anggota komunitas online dalam melakukan pertemuan fisik (kopi darat). (Hummel \& Lechner 2002).

Kemajuan teknologi informasi dan komunikasi pada awalnya diyakini akan mengubah konsep interaksi antara trip generation dan trip production menjadi tidak lagi tinggi. Hal ini disebabkan karena sifat teknologi informasi dan komunikasi yang diyakini menggantikan perjalanan. Apakah hal ini berlaku untuk aktivitas komunitas online? Hal ini masih menjadi sesuatu yang perlu untuk diteliti dan dibuktikan.

Aktivitas komunitas online diyakini akan mempengaruhi pergerakan yang ditimbulkan. Apabila selama ini perencana transportasi masih mendasarkan pada aktivitas di dunia nyata sebagai analisis sistem transportasi maka perlu adanya kepedulian akan aktivitas yang berlangsung tidak hanya yang didasarkan pada aktivitas di dunia nyata.

Secara garis besar dapat dikatakan bahwa dengan mendasarkan pada gagasan Manheim tentang hubungan antara sistem aktivitas dan sistem pergerakan maka kedudukan komunitas online dapat sistem transportasi dapat dijelaskan pada gambar 5 .

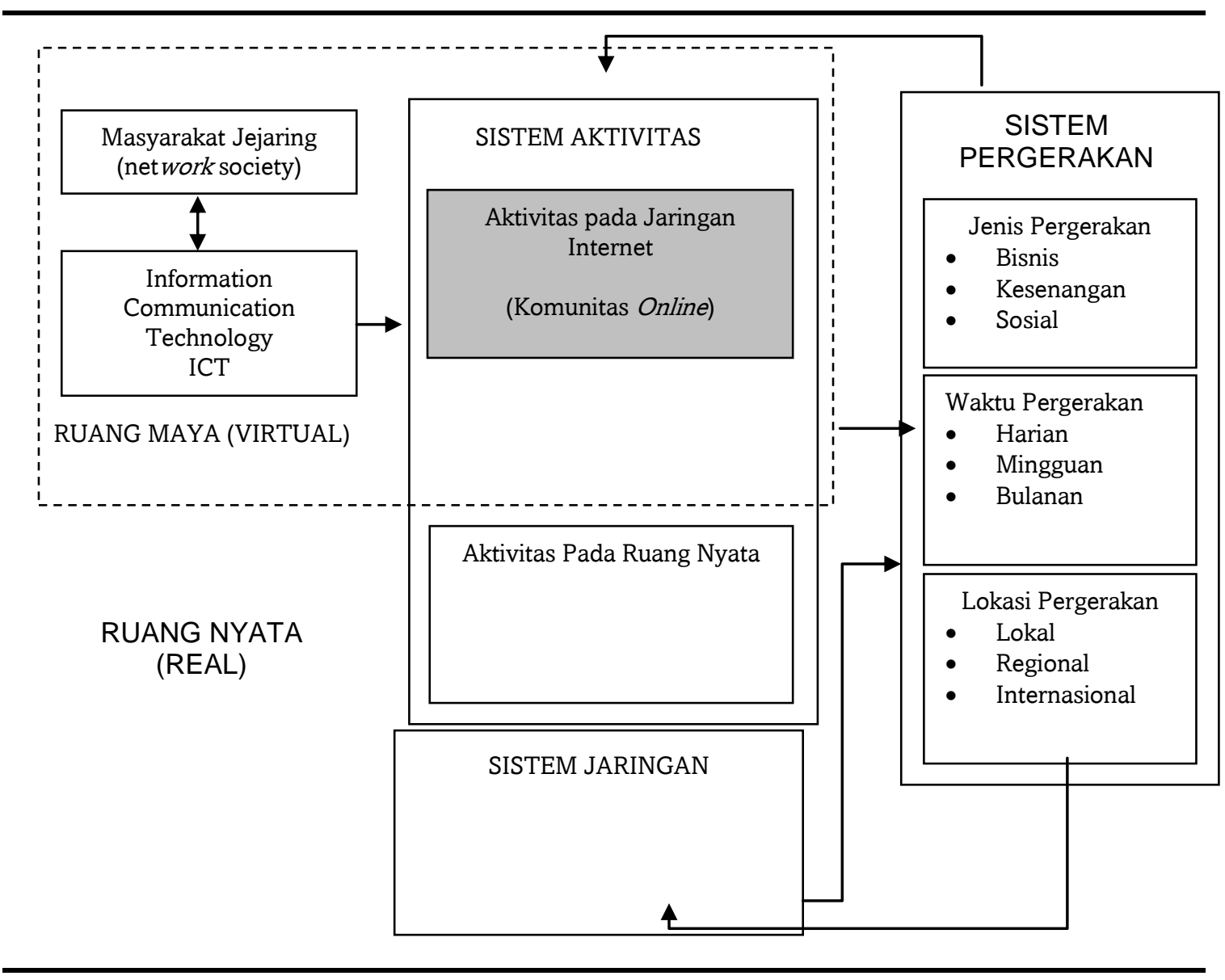

Gambar 5. Kedudukan Komunitas Online Pada Sistem Transportasi 
Dari gambar di atas dapat dijelaskan bahwa fenomena network society telah mengalami perkembangan yang sangat pesat karena dukungan dari teknologi informasi dan komunikasi. Hal ini berimbas pada sistem aktivitas yang tidak lagi hanya berdasarkan ruang nyata namun juga ruang maya. Komunitas online merupakan contoh dari aktivitas yang berdasar ruang maya. Karakteristik aktivitas komunitas online yang meretas hubungan manusia yang berdasarkan jarak menjadi tidak berjarak lagi. Hal ini berimplikasi pada pola pergerakan yang ditimbulkan tidak hanya pada lokasi asal dan tujuan namun juga pada frekwensi dan penggunaan modanya. Hal ini juga berakibat pada relevansi gagasan trip attraction dan trip generation pada pendekatan perencanaan transportasi terdahulu.

\section{Kesimpulan}

Dari uraian di atas maka dapat ditarik dua kesimpulan besar yaitu :

1. Bahwa telah terjadi pergeseran gagasan folk yang dikemukakan oleh Patrick Geddes seiring dengan perkembangan masyarakat perkotaan akibat adanya teknologi informasi dan komunikasi yaitu pada ruang yang digunakan beraktivitas yang tidak lagi hanya berbasis ruang nyata (real space) namun juga terjadi pada ruang maya (virtual space) dan jenis hubungan di dalam dan antar komunitas yang tidak lagi struktural, hirarkis dan rigid menjadi lebih fleksibel.

2. Pergeseran terminologi tersebut dalam konteks perencanaan transportasi telah berimplikasi pada perlunya penyempurnaan gagasan Manheim tentang hubungan mendasar sistem aktivitas dan pergerakan yang tidak lagi hanya mendasarkan pada aktivitas berbasis ruang nyata namun juga yang berbasis ruang maya. Aktivitas yang berbasis ruang maya ini juga akan berimplikasi pada pemahaman trip generation dan trip attraction yang sering digunakan dalam analisis pola pergerakan.

\section{Daftar Pustaka}

Albrechts, L., Mandelbaum, S,J., (2005) The network society a new context for planning. Routledge, New York.

Audirac, I., (2005) Information Technology and Urban Form: Challenges to smart growth international., Regional Science Review 28, 2: 119-145. (diunduh tanggal 24 Pebruari 2011) http://irx.sagepub.com/content/28/2/119.abstract

Cairncross, F., (1997) The Death of Distance : How the Communications Revolution Will Change Our Lives, Havard Business School Press, Boston.

Cardoso, G., (2006) The Media in the Network Society: Browsing, News, Filters dan Citizenship, Lisboa, Portugal, CIES, Centre for Research and Studies in Sociology.

Castells, M., (2010) The Information Age: Economy, Society and Culture Volume I: The Rise of The Net work Society, Second Edition, A John Wiley \& Son, Ltd, Publication.

Castells, M., (2009) Communication Power, Oxford University Press.

Castells, M., Cardoso, G., (2005) The Network Society: From knowledge to policy ., Washington, DC: Johns Hopkins Center for Transatlantic Relations.

Castells, M., (1989) The Informational City : Information Technology, Economic Restructuring, and UrbanRegional Process, Blackwell Oxford UK \& Cambridge USA.

Cattan, N., (2007) Student Mobility, Gender and Polycentrism in Europe"Cities and networks in Europe. A critical approach of polycentrism, Nadine Cattan (Ed.)

François D., Shang, D., (2009) Becoming mobile in contemporary urban China: How increasing ICT usage is eformulating the spatial dimension of sociability ., International Development Research Centre. diunduh tanggal $24 \quad$ Pebruari 2011) http://unpan1.un.org/intradoc/groups/public/documents/unpan/unpan038610.pdf

Gamal, H,E., (2010) Network society: A social evolution powered by youth. Global Media Journal Arabian Edition Fall/Winter., Vol. 1, No. 1, pp. 16-26. (diunduh tanggal 24 Pebruari 2011) http://www.gmjme.com/gmj_custom_files/volume1_issue1/articles_in_english/volume1-issue1-article-16-26.pdf 
Geddes, Patrick, 1915, Cities in Evolution:An Introduction to The Town Planning Movement and to the Study of Civics, Williams and Norgate, London

Golob, T. (2001). Travel Behavior.Com: activity approaches to modeling the effects of information technology on personal travel behavior. Institute Transportation Studies Universities of California. (diunduh tanggal 17Maret 2011) http://www.uctc.net/papers/573.pdf

Graham, S., (2001) Information technologies and reconfigurations of urban space ., International Journal of Urban and Regional Research, Volume 25. (diunduh tanggal 24 Pebruari 2011) http://onlinelibrary.wiley.com/doi/10.1111/1468-2427.00318/abstract

Gustavo, C.,(2006) The Media in the Network Society: Browsing, News, Filters and Citizenship, Lisboa, Portugal. CIES - Centre for Research and Studies in Sociology.

Hajer, M., Zonneveld, W., (2000) Spatial Planning in the Network Society—Rethinking the Principles of Planning in the Netherlands., European Planning Studies, Vol. 8, No. 3. (diunduh tanggal 24 Pebruari 2011) http://www.maartenhajer.nl/upload/HAJER\%20Spatial\%20Planning\%20in\%20the \%20Net work $\% 20$ So ciety.pdf

Hampton, K, N., (2007) Neighborhoods in the Network Society: The e-Neighbors ., Study Information Communication \& Society., (c) Taylor \& Francis. (diunduh tanggal 24 Pebruari 2011/http://www.mysocialnet work.net/downloads/eneighborsplace18.pdf

Hummel, J. \& Lechner, U. (2002). Social Profiles of Virtual Communities. Proceedings of the 35th Hawaii International Conference on Systems Sciences

Kanafani, Adib, 1983, Transportation Demand Analysis, Mc Graw-Hill Book Company, United States of America.

Manheim, M. (1979). Fundamentals of transportation systems analysis. MIT Press,

Meyer and Miller, (2001), Urban Transportation Planning second edition, Mc Graw-Hill, United States of America.

Morlok, E., (1997) Perencanaan Transportasi, Erlangga, Jakarta

Ohmori, N., (2006) Connected anytime: telecommunications and activity-travel behavior from Asian

perspectives, paper presented at the 11th International Conference on Travel Behaviour Research, Kyoto.

Social Media World Forum Asia, (2010) (http://www.financeindonesia.org/content.php?279-Social-MediaWorld-Forum-Asia-2010

Soekanto, Soerjono. 1990. Sosiologi Suatu Pengantar. PT Radja Grafindo. Jakarta. 